\title{
The Political Economy of Regulation
}

Thomas P Lyon (ed)

Reviewed by

S L Rao

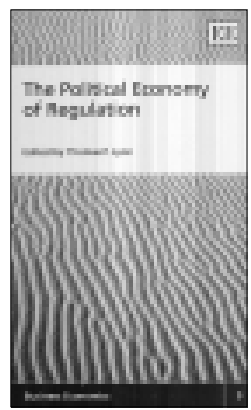

Hardbound

663 pp. 2007

ISBN 978-1-84376-620-9

International Journal of Regulation and Governance 7(2): 201-206

This book contains a collection of selected readings on the subject of independent regulation. The articles in the book have appeared in reputed journals including the Journal of Law and Economics, Bell Journal of Economics, Review of Economic Studies, Journal of Political Economy, Quarterly Journal of Economics, American Economic Review, Virginia Law Review, Journal of Law, Economics and Organization, RAND Journal of Economics, Economic Journal, and Western Economic Journal. The earliest article appeared in 1960 and the latest in 2005 . The earliest article is by the economist $\mathrm{R} \mathrm{H}$ Coase on 'The Problem of Social Cost'. There are two other articles from 1967 and 1968, eight from 1974-1978, seven from 1982-1989, three from 1993-1996, and two were published in 2000 and 2005.

The book is divided into four parts. It starts with five articles on 'Targets for Regulation' that consider issues like the need to regulate utilities, franchise bidding for natural monopolies, the problem of social cost, prices versus quantities, and minimum quality standards.

The second part, over 221 pages with ten articles, is on 'Causes and Consequences of Regulation'. It looks at welfare costs of tariffs, monopolies, and theft; a general theory of regulation; a theory of competition among pressure groups for political influence; capture and ideology in the economic theory of politics; the demand for state regulation of the electric utility industry; polluters' profits and political response: direct controls 
versus taxes; a positive theory of environmental quality regulation; environmental regulation and whose self-interests are protected; and the effects of automobile safety regulation.

The third part has seven articles on 'Political control, Administrative Discretion, and Enforcement' and considers bureaucratic discretion and legislative control; political control of regulator agencies; a comparative analysis of telecommunications regulation to study the institutional foundations of regulator commitment; the revealed preferences of a government bureaucracy; regulatory opportunity and investment behaviour in the US electric utility industry; a positive economic theory of regulatory enforcement; and issues of poor compliance despite a 'good' regulatory agency.

The final part consists of two articles on 'Self-Regulation' and covers informal regulation of industrial pollution in Indonesia, and the political economy of corporate environmentalism.

The collection thus emphasizes that independent regulation is a potpourri of economic theory, political science, law, and administration. Regulators have to stride all four areas without expertise in any of them. In designing new regulatory agencies, an understanding of this mixture is essential if the design is to be effective. New regulators would be well-advised to introduce themselves to this collection which will give them a useful background to the pressures they will encounter and how they can deal with them.

This reviewer does not propose to discuss the articles in the book in detail except to comment that they are all well selected and make their conceptual and practical points amply clear. As one of those who headed a new regulatory agency in India where the concept itself was little understood, he found that each article addressed some of his concerns at that early time in the late 1990s when he was heading the new CERC (Central Electricity Regulatory Commission) in India. This was in a federal environment where electricity was a concurrent subject, which meant that the central commission was responsible for interstate while the state commissions were responsible for intrastate issues in power. The CERC had no authority over the state commissions; over atomic energy even when it was consumed by the civilian sector over the grid; over the major input cost namely fuels-coal, gas, and others even when it was regulating an undertaking that had captive coal mines for generating electricity. Despite these limitations the CERC was able to establish a national Grid 
Code, control the wide frequency variations over the country using commercial mechanisms, introduce grid discipline, regulate a system dominated by central-government-owned undertakings, and balance the interests of the distribution entities which were stategovernment owned but subject to tariffs from central-governmentowned undertakings that were able to get higher tariffs than justified from their owners, the central government.

Markets are accepted as being extraordinarily effective for providing people with goods and services they desire. However, markets are imperfect. Political institutions have been developed even in most market-oriented countries to regulate market processes and direct them towards the common good. The United States is perhaps the most heavily regulated market economy. It is also the regulatory system that has been most studied.

Independent regulatory agencies target specific industries or could cut across many different industries. The Federal Communications Commission and the Federal Trade Commission are examples of each. In USA, many state regulatory agencies regulate a broad mix of government activities-for example, control of monopoly prices, preventing collusion, granting broadcast licenses, ensuring workplace safety, certifying the safety and efficacy of new medicines, and protecting the natural environment. In India, many of these activities are with departments of government who perform them in a non-transparent manner. However, the Right to Information Act does give the opportunity of scrutinizing these decisions more closely. Independent regulatory agencies at the centre and states in India exist for electricity and there is a central one for telecommunications. Many others are either starting or being considered. There are independent regulatory agencies being considered for technical education, pharmaceutical pricing, civil aviation, and so on.

There is little in common between independent regulatory agencies in India in terms of their functions, powers, finances, staffing, selection and termination of members, and so on. For example, there are major issues with the accountability of these agencies that have to be addressed. For example, who holds them responsible if their orders are often overturned by higher courts? Similarly, when there are different agencies, is there such a concept as regulatory law that uses as precedents, the orders issued by other agencies in other parts of the country or in other regulatory jurisdictions? This book also does not touch on these 
aspects of regulatory agencies, namely whether there should be a common framework of functions, methods of functioning, financing, and other such aspects for all.

Little attempt appears to have been made in USA at estimating the benefits of regulation, though there seem to be estimates of regulatory costs. One estimate that is quoted, of roughly $8.2 \%$ of GDP (gross domestic product) in 2002 seems high, though it is not known what is included in these costs and whether the estimate relates to overall regulatory costs or specifically relates only to independent regulatory agencies. There is no such estimate in India. There is little information on costs of compliance and not merely that of the direct costs of the agencies themselves.

Economists have approached regulation from different perspectives. One was the solving of the situation of market failures. Another was the descriptive approach, developing a politicaleconomic understanding of the causes and consequences of regulation. A third was the desire to find ameliorations to market failures-in other words to safeguard the interests of those who might otherwise have been unable to safeguard themselves from more powerful elements in the market.

The editor, Thomas Lyon, uses the concept of the 'policy life cycle' to organize the readings in this book. He says that typically, there are four stages development, politicization, legislative and implementation. In the development stage, events occur that lead various segments of the public to become aware that a problem exists. The second stage is politicization, when the issue acquires a label, opinion leaders begin to discuss the problem in public in which the issue becomes a label, the news media become more active in covering the issue, and interest groups begin to mobilize around the issue. In the legislative stage, political leaders take action to create new laws addressing the issue. Once there is legislation, it is unlikely to be eliminated because there is a fundamental transformation. The inertia that policies are not easily reversed after legislation keeps it in place. That is why much thought must be given before creating a new agency. In the final stage, the administrative agencies work out the details under which the agency will function.

In the instances of Indian agencies, their formation was more because of the pressure from funding agencies like the World Bank and private investors overseas. Ironically, new private investments in India in both telecommunications and electricity have come from domestic and not foreign sources. 
Dr Lyon points out that regulation involves all four phases and not merely implementation. The book presents research encompassing all phases of the policy life cycle. The regulator is a policy maker in the area given to the agency, and not a mere implementer and this book recognizes this.

The essays discuss the different types of market failure that lead to the formation of an independent regulatory agency. These are market power, externalities and information asymmetries. Some papers discuss the causes and consequences of regulation in each of these three areas.

There are essays in Part II that look in detail at political control of administrative agencies, an issue that has been handled variably in India for different agencies. The legislation that creates regulatory agencies must ensure that future regulators behave in accord with the desire of the legislatures that created the agency. However, this also requires that the legislatures are clear on what they want. In India, this has not been the case and the legislation is many times a bureaucratic creation. In the chapters that discuss how regulators use the discretion given to them under the law, it is concluded that forbearing from applying legal sanctions and instead bargaining to ensure compliance can be cost effective in some circumstances. Of course this demands that the agency functions in a different way than from a procedure bound court and has the ability to engage in such bargaining.

In discussing natural monopolies it is argued that competition is possible for the market when it may not be so in the market. India is witness to this with the successful introduction of tariffbased competitive bidding for new power projects as with other infrastructure projects in roads, airports, and others.

Sometimes there are externalities when third parties get affected by transactions. Again, in such cases, regulation minimizes adverse impacts.

Self-regulation is intended to prevent mandatory regulation. Recent evidence in USA has shown for example that auditors, who were subject to self-regulation by their Association, had grossly violated ethical norms of behaviour. The SarbannesOxley Act introduced major additional costs on companies to ensure that misuse of auditors and auditors taking advantage to make more money, was avoided.

This is an outstanding collection of essays on regulation. The book must be on every regulator's shelf and be compulsory reading for all new regulators. 